\title{
PERANCANGAN PONDOK PESANTREN MODERN DENGAN PENDEKATAN ARSITEKTUR MODERN DI DEPOK
}

\author{
Mukhamad Risa Diki Pratama, Atie Ernawati, Yulistiana
}

\author{
Program Studi Arsitektur, \\ Fakultas Teknik, Matematika dan Ilmu Pengetahuan Alam \\ Universitas Indraprasta PGRI \\ mrdikipratama@yahoo.com
}

\begin{abstract}
Abstrak
Mewujudkan pendidikan islami yang mandiri dan modern dengan tidak meningalkan nilai-nilai agama yang ada serta mengatasi keterbatasan akan sekolah berbasis Pondok pesantren dan juga menghindari pahampaham yang bertentangan dengan Islam. Memberi pemahaman pada masyarakat terutama pada orang tua untuk memasukan anaknya pada sekolah berbasis pondok pesantren sehingga menghindari hal-hal yang tidak di inginkan. Menghilangkan pemahaman pondok pesantren tentang adanya penyakit kulit dengan menciptaka ruang asrama yang lebih layak huni dan kamar mandi yang terletak didalam kamar santri. Metode penelitian yang digunakan adalah studi survei lapangan, dokumentasi, dan wawancara. Data yang di dapat nantinya akandigunakan untuk proses desain lebih lanjut.
\end{abstract}

Kata-kunci : Pondok Pesantren, Modern, Arsitektur, Depok

\begin{abstract}
Design of Islamic boarding school has purpose to implement Islamic education, help goverment provide school with boarding system, prevent people from misguided, Protect student from bad influence and eliminate the image of Islamic boarding school that student can get skin disease. For this purprose, desiger create more feasible space. The one of the way is put bathroom inside the student room. Method used to get primelinary data is survey, interview and took picture. This data is used to be a basic information in designing the boarding school.
\end{abstract}

Keyword : Islamic boarding school, Modern, Architecture, Depok 


\section{PENDAHULUAN}

\section{Latar Belakang}

Dinamika zaman telah berganti sehingga pola sistem masyarakat terus berubah dari pola masyarakat yang tradisional menjadi masyarakat yang lebih modern, pendidikan pun harus menyesuaikan pola masyarakat yang modern. Pada umunya banyak pesantren yang menggunakan pola pendidikan tradisional yaitu pola salafiyah. khalafiyah merupakan model pendidikan yang mengajar terhadap kehidupan pesantren, pesantren adalah salah satu model pendidikan yang sudah lama mengajar dalam kehidupan masyarakat Indonesia, bahkan pesantren merupakan cikal bakal dari sistem pendidikan islam yang ada di tanah air ini.

Mayoritas penduduk di Depok beragama islam dan perubahannya sangat pesat. Hal tersebut dikuatkan dengan berdirimya beberapa sekolah yang mengutamakan sistem pendidikan agama islam. Secara istilah pesantren adalah lembaga pendidikan islam dimana para santri biasa tinggal di pondok (asrama) dengan materi pengajaran kitab-kitab klasik dan kitab-kitab umum bertujuan untuk menguasai ilmu agama islam secara detail serta mengamalkan sebagai pedoman hidup keseharian dengan menekankan penting moral dalam kehidupan bermasyarakat.

\section{Tinjauan Pustaka}

Pengertian Pondok Pesantren

Pondok Pesantren Modern adalah sebuah asrama pendidikan atau biasa disebut pondok pesantren, di mana para siswanya semua tinggal bersama dan belajar di bawah bimbingan guru yang lebih dikenal dengan sebutan Kiyai dan mempunyai asrama untuk tempat menginap santri.

Pesantren merupakan dua istilah yang menunjukkan satu pengertian.
Pesantren menurut pengertian dasarnya adalah tempat belajar para santri, sedangkan pondok berarti rumah atau tempat tinggal sederhana.. Di samping itu, kata pondok mungkin berasal dari Bahasa Arab Funduq yang berarti asrama atau hotel, pesantren juga dapat dipahami sebagai lembaga pendidikan dan pengajaran agama, umumnya dengan cara nonklasikal, di mana seorang kiai mengajarkan ilmu agama Islam kepada santri-santri berdasarkan kitab-kitab yang ditulis dalam bahasa Arab oleh Ulama Abad pertengahan, dan para santrinya biasanya tinggal di pondok (asrama) dalam pesantren tersebut.

\section{Pengertian Arsitektur Modern \\ modern dapat diartikan sebagai} segala sesuatu yang memiliki kaitan dengan setiap hal yang berkembang pada masa kini atau yang menunjukkan karakter kekinian. Untuk suatu hunian, hunian yang modern berarti hunian yang memiliki dan menunjukkan adanya ciri Arsitektur Modern. Hunian yang memiliki gaya Arsitektur Modern harus mampu menghadirkan gaya hidup masa kini di dalam bangunan.

Arsitektur Modern memiliki prinsip yaitu fungsional dan efisiensi. Fungsional berarti bangunan tersebut benar-benar mampu mewadahi aktifitas penghuninya, dan efisiensi harus mampu diterapkan ke berbagai hal; efisiensi biaya, efisiensi waktu pengerjaan dan aspek free maintenance pada bangunan.

Karakteristik Arsitektur modern :

1. Menolak gaya lama;

2. Menolak bordiran atau ukiran dalam bangunan;

3. Menyederhanakan bangunan sehingga format detail menjadi tidak perlu;

4. Mengadopsi prinsip bahwa bahan dan fungsi sangatlah menentukan hasil bangunan; 
5. Memandang bagunan sebagai mesin.

\section{METODE PERANCANGAN}

Penelitian ini dilakukan dengan pendekatan penelitian survey, dengan tujuan dapat merasakan langsung kehidupan Pondok Pesantren. Metode ini menggunakan metode kualitatif. Permasalahan dianalisa berdasarkan datadata survei lapangan. Hasil survei berupa analisa pribadi dan hasil wawancara akan dirunutkan lebih mendalam dengan tujuan memahami secara utuh yang dimiliki Pondok Pesantren. Lingkup penelitian berfokus pada aspek estetika bentuk, material, serta kehidupan keseharian Pondok Pesantren dengan tujuan mengangkat nilai-nilai Modern yang akan menjadi kajian utama Standart Pondok Pesantren. Data fisik berupa model yang menjadi Pondok Pesantren dianalisa untuk kebutuhan perancangan. Data olahan fisik berupa perancangan produk disesuaikan dengan hasil analisa tapak di lokasi perancangan.

Bangunan modern yang menjadi panutan desain adalah bentuk bangunan yang indah, diberikan berbagai aksesoris dan hiasan dinding, Beberapa bangunan pondok pesantren masih berupa bangunan tradisional yang masih dipertahankan sampai sekarang.

Bangunan Pondok pesantren masih bangunan belanda, seperti dinding memakai gamping, dan lantai masih dilapisi semen tanpa keramik. Pada desain ini dinding dibuat senyaman mungkin yang tidak menimbulkan lembab pada permukaan. Dan lantai memakai keramik yang nyaman untuk dihuni pada ruangan. Pada kamar asrama dibuat senyaman mungkin dengan maksimal hanya 6 santri dan kamar mandi berada dalam kamar, santri merasakan nyaman dan tidak takut adanya penyakit kulit yang sering dibicaran pada pondok pesantren. Pada atap terdapat roof garden sehingga mengurangi panas pada ruangan tersebut.

\section{Metode Pengumpulan Data}

Metode yang digunakan adalah survei langsung ke Pondok pesantren. Metode survei disesuaikan dengan objek penelitian berupa penggunaan teknologi konvensional pada bangunan itu sendiri.

Konstruksi bangunan pondok pesantren terbentuk atap yang di atasnya terdapat roof garden, rangka menggunakan beton. Struktur pada pondasi memakai pondasi menerus pada bangunan sedang, dan pondasi tiang pancang pada bangunan bertingkat tinggi.

\section{PEMBAHASAN DAN HASIL RANCANGAN}

\section{Tinjauan Tapak}

Lokasi memegang peranan penting dalam menentukan keberhasilan suatau pondok pesantren, terutama dalam memenuhi kegiatan-kegiatan penghuninya. Lokasi pondok pesantren berada tepat di Grand Depok City.

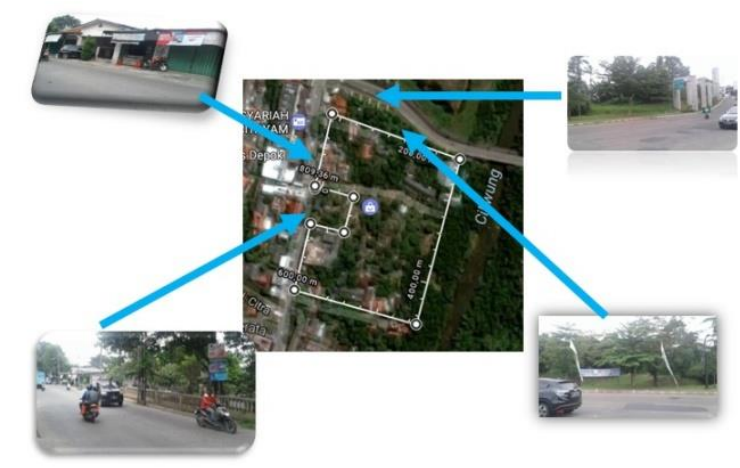

Gambar 1. Lokasi dan Layout Tapak

\section{Konfigurasi Tapak}

Pada lokasi terpilih bentuk tapak sangat kompleks, maka bentuk massa tidak mengikuti bentuk tapak. Bentuk massa bangunan diambil dari bentukbentuk geometris seperti: persegi panjang, lingkaran, atau persegi. 


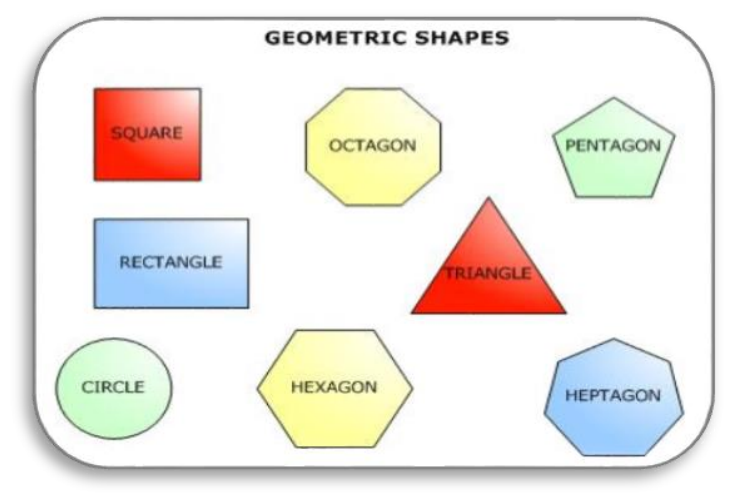

Gambar 2. Konfigurasi Tapak

\section{Perzoningan}

Berdasarkan hasil analisa tapak, maka dapat di tarik kesimpulan penzoningan dalam peletakan gubahan massa bangunan yang terdiri dari :

1. Zona private

Yaitu yang terdiri dari Gedung

Kantor ( R.kepala Sekolah, R.

Pengajar, R. Administrasi, R.

Dokumen, R. Pertemuan), Ruamah

Kyai, Gedung Sekolah, Gedung Asrama.

2. Zona public

Yaitu yang terdiri dari Lapangan, Masjid, Parkiran, Taman.

3. Zona service

Yaitu yang terdiri dari , Dapur

+ R.makan

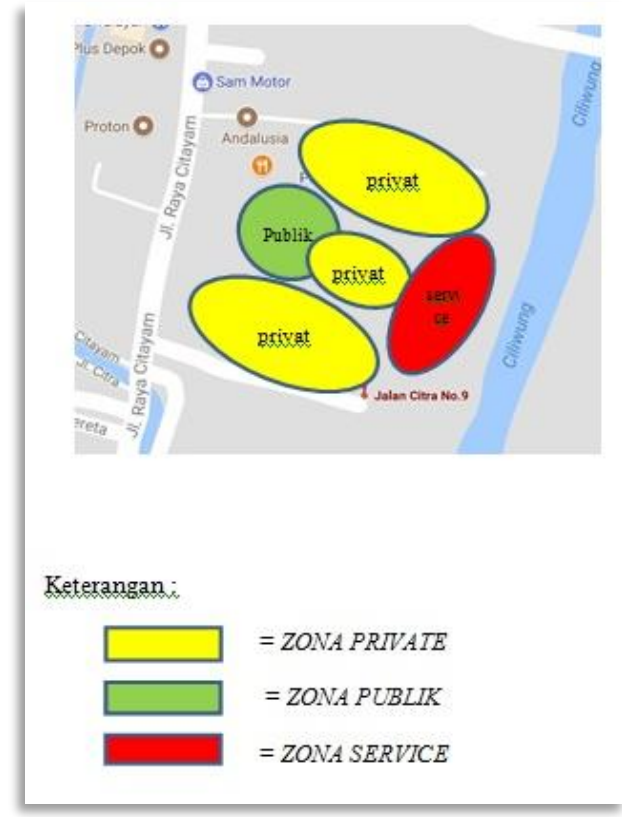

Gambar 3. Perzoningan

\section{Tranformasi Bentuk}

Transformasi sebagai teknik permainan bentuk dengan memanipulasi bentuk Transformasi memiliki tujuan menghasilkan bentuk baru. Dengan permainan Bentuk secara terus menerus akan menghasilkan suatu komposisi bentuk yang mencerminkan pencitraan (sutanto dan Surya, 2000:26-28)

Namun penulis mengedepankan proses perancangan dengan mengedepankan tema modern dalam perancangan Pondok Pesantren Modern itu sendiri, pemilihan material serta penunjang bangunan di sesuaikan dengan kebutuhan dari segi bangunan.

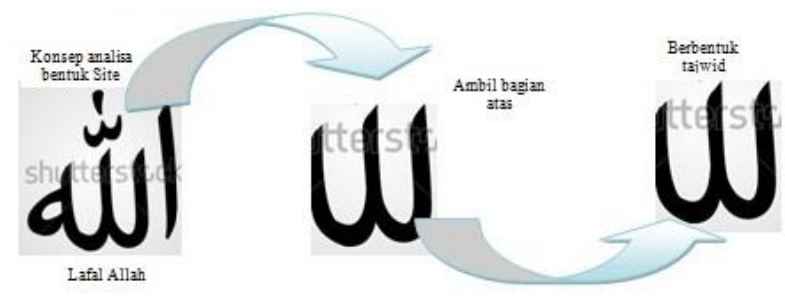

Gambar 4. Gubahan masa site

Pada bagian site gubahan masa diambil dari lafadz allah SWT.

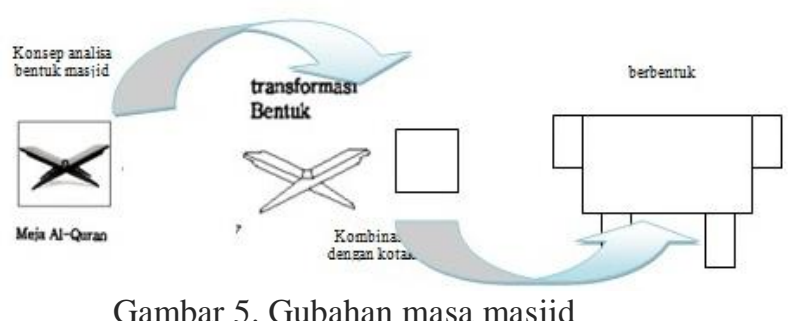

Gambar 5. Gubahan masa masjid

Pada bagian masjid gubahan masa diambil dari laker Al-quran.

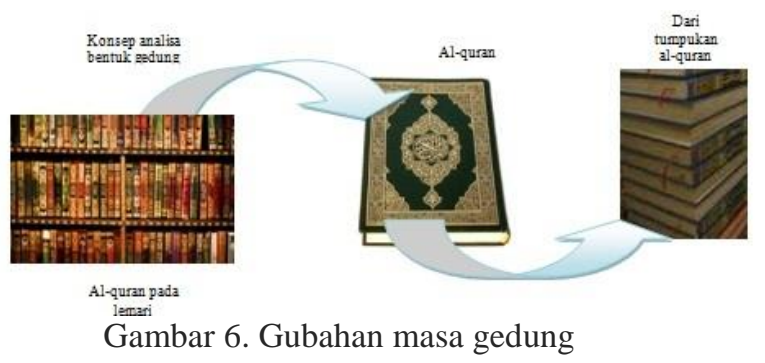


Pada bagian gedung gubahan masa diambil dari tumpukan Al-quran.

\section{Potensi dan kelemahan Tapak}

Letak lahan yang sangat strategis, yaitu berdekatan dengan salah satu terminal Depok yang tak jauh dari tapak sangat berpotensi untuk mengembangkan bangunan dan fungsinya sehingga dapat menjadi icon baru Depok selain sebagai tujuan pendidikan, selain itu posisi jalannya yang terletak persisi didepan rencana tapak merupakan jalan penghubung antara 2 jalan, yaitu arah depok - citayam.

Jadi potensi dan kelemahan site dapat disimpulkan sebagai berikut

1. Potensi site

a. Kondisi kontur tanah pada site cenderung datar.

b. Akses ke site cukup mudah / dekat terminal.

c. Cukup vegetasi sebagai perindang.

2. Kelemahan site

a. Pada siang udara terasa sangat panas.

b. Penataan trotoar yang kurang baik bagi pedestrian.

c. Luas badan jalan yang sempit.

d. Suasana jalan yang macet ketika waktu pagi dan sore hari (jam berangkat kerja dan pulang kerja) dan pada akhir pekan.

\section{Penanggulangan Kebakaran}

Indoor Hydrant

Berupa gulugan selang dan hydrant sebagai sumber airnya, digunakan untuk memadamkan api yang cukup besar. Diletakan di tempat-tempat strategis yang mudah dan dikenali serta di tempat yang memiliki resiko kebakaran yang tinggi. Sumber air hydrant diambil dari ground tank untuk kebutuhan air sehari-hari.

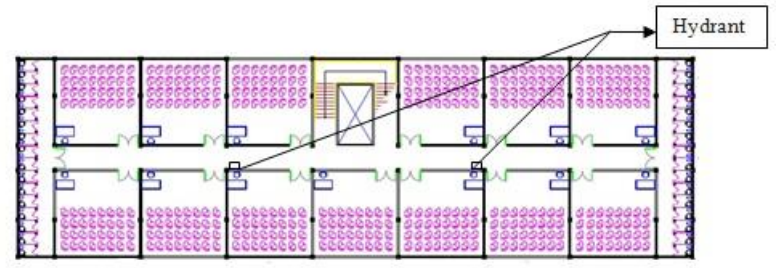

Gambar 7. Denah Indoor Hydrant

\section{Konsep roof garden}

Selain Karena lahan telah disesaki bangunan, maka sasaran peroleh sel-sel hijau daun beralih pada hambaran atap datar bangunan dan atas basement yang justru lebih banyak dibanjiri cahaya matahari, sebagai sarana untuk mengurangi beban panas dalam bangunan dan juga karbon dioksida pada lingkungan.

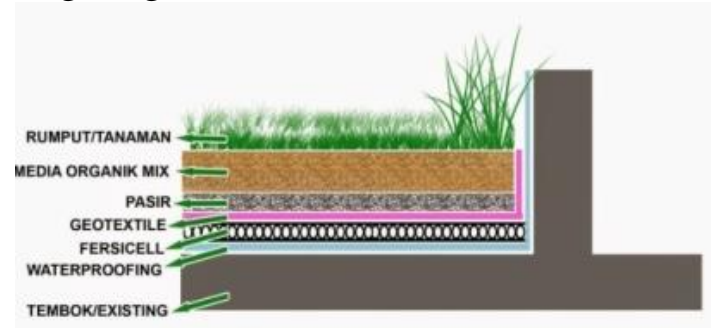

Gambar 8. Konsep roof garden

\section{Desain}

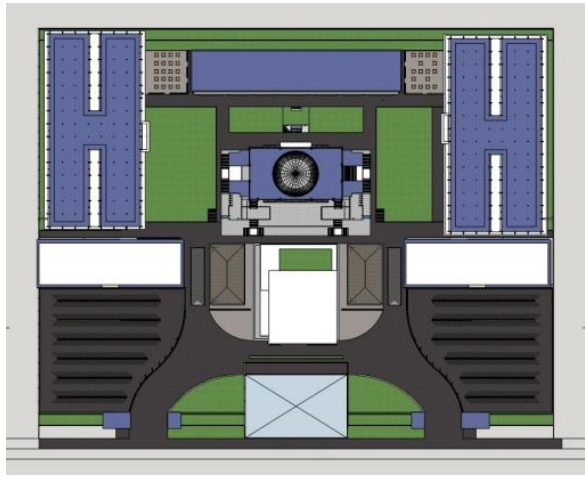

Gambar 9. Block Plan

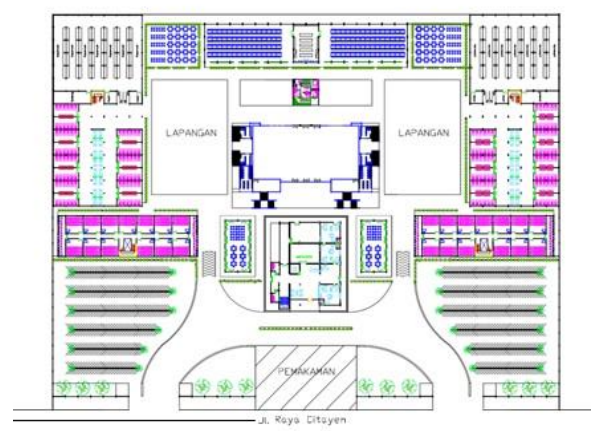

Gambar 10. Site Plan 


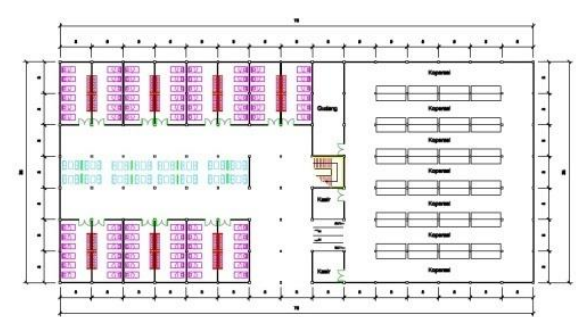

Jambar 11. Denah asrama lt.1

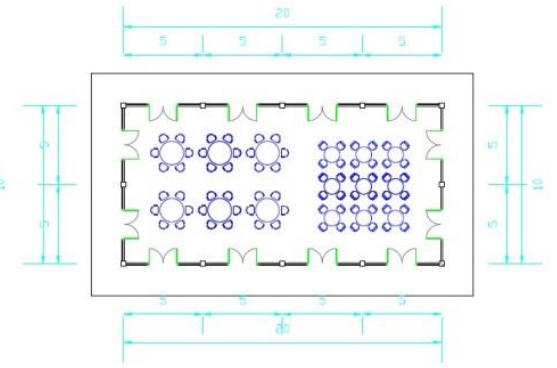

Gambar 13. Denah Ruang Pertemuan

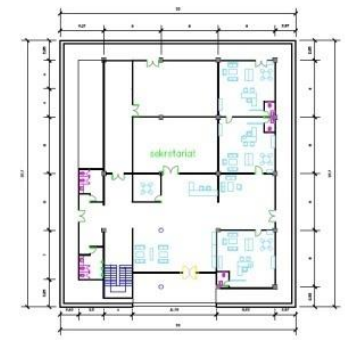

Gambar 15. Denah Kantor Lt.1

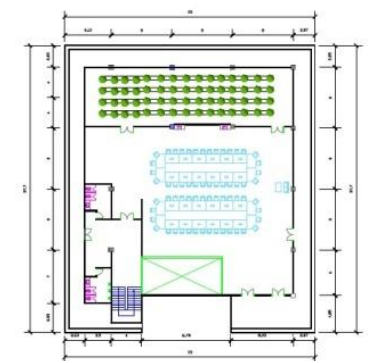

Gambar 17. Denah Kantor Lt.3

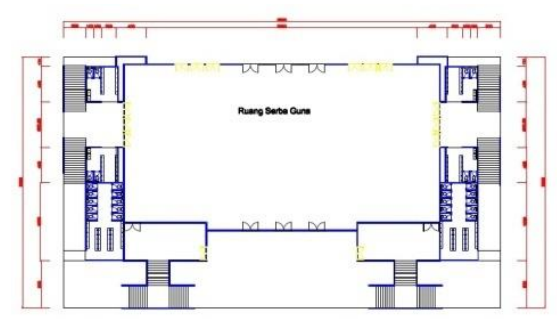

Gambar 19. Denah masjid Lt.dasar

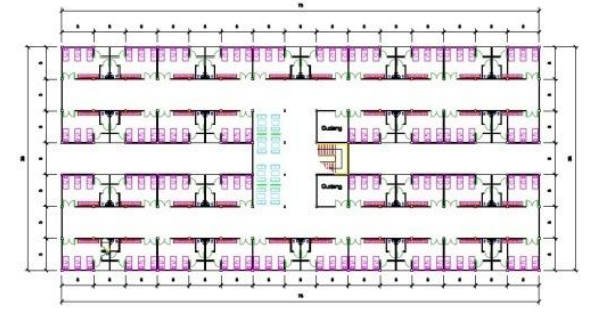

Gambar 12. Denah asrama lt.typical

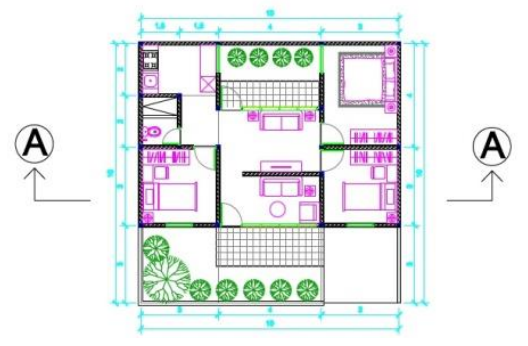

Gambar 14. Denah rumah kyai

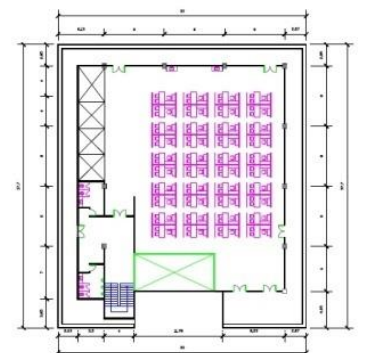

Gambar 16. Denah Kantor Lt.2
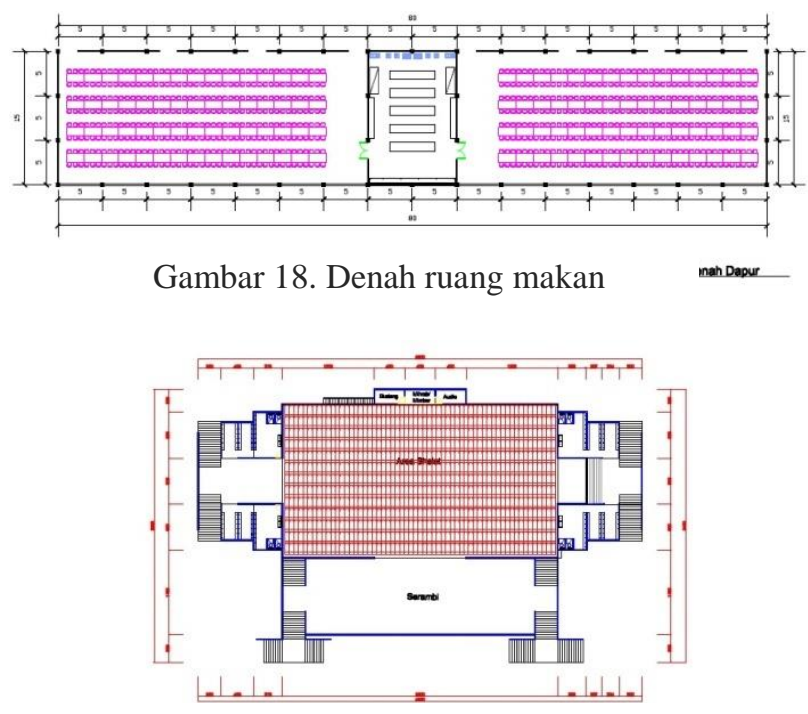

Gambar 20. Denah masjid Lt.1 


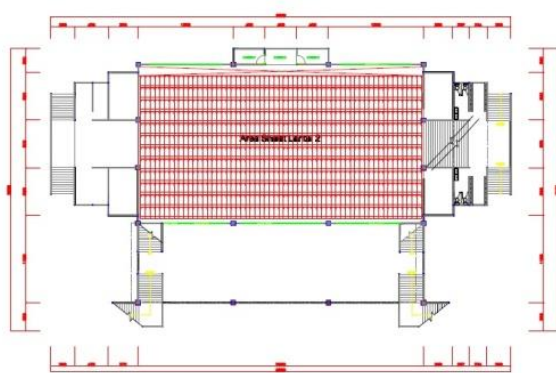

Gambar 21. Denah masjid Lt.2

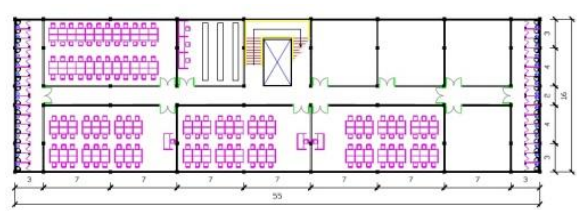

Gambar 23. Denah sekolah 1t.1-2

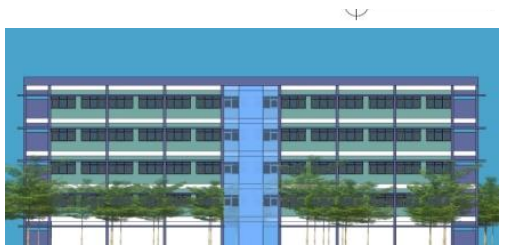

Gambar 25. Tampak Depan Sekolah

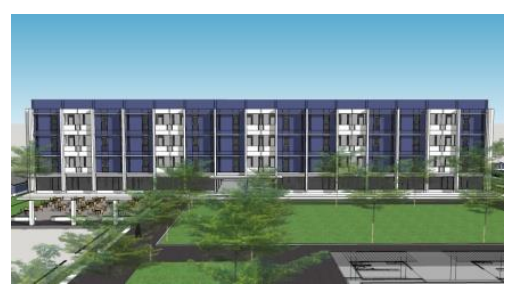

Gambar 27. Tampak Depan Asrama

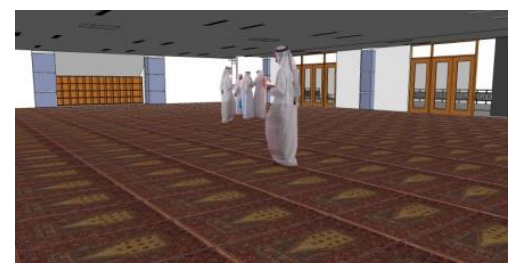

Gambar 29. Interior masjid

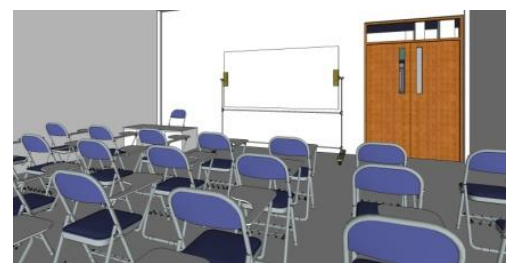

Gambar 31. Interior Sekolah

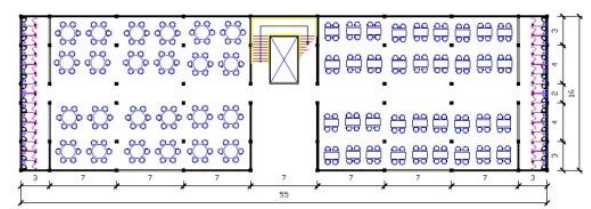

Gambar 22. Denah sekolah lt.dasar

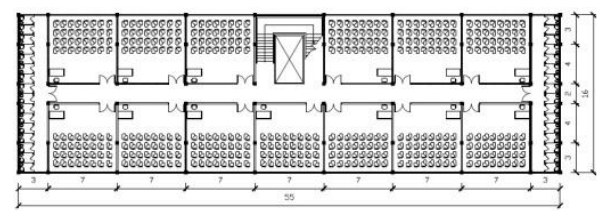

Gambar 24. Denah sekolah lt.3-4

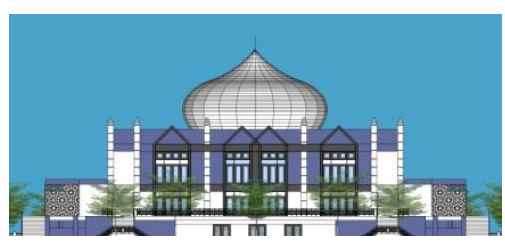

Gambar 26. Tampak Depan Masjid

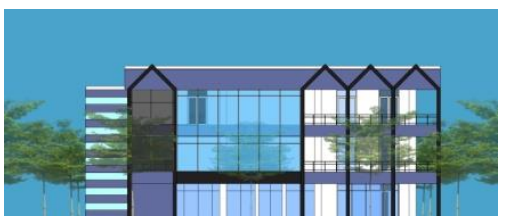

Gambar 28. Tampak Depan Kantor

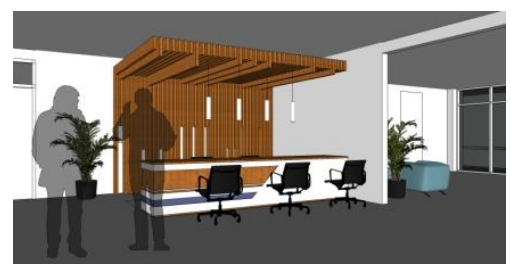

Gambar 30. Interior Kantor

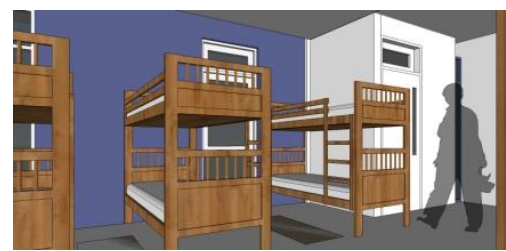

Gambar 32. Interior sekolah 


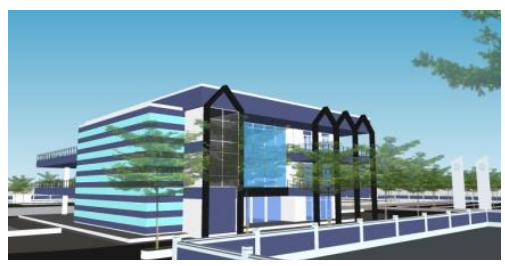

Gambar 33. Perspektif 1

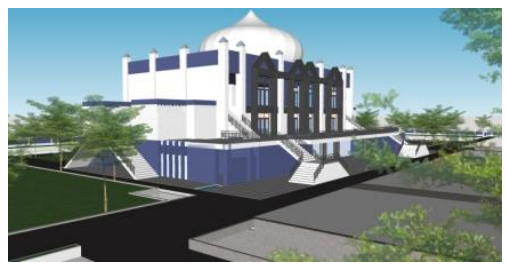

Gambar 35. Perspektif 3

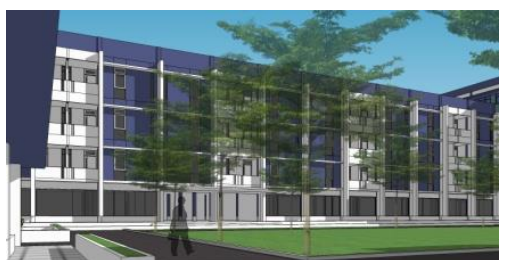

Gambar 34. Perspektif 2

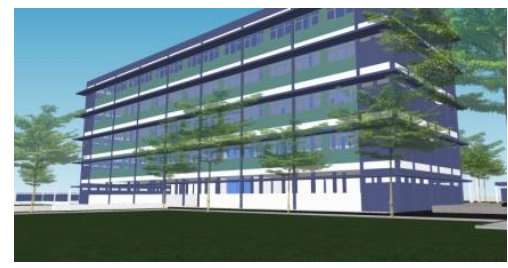

Gambar 36. Perspektif 4

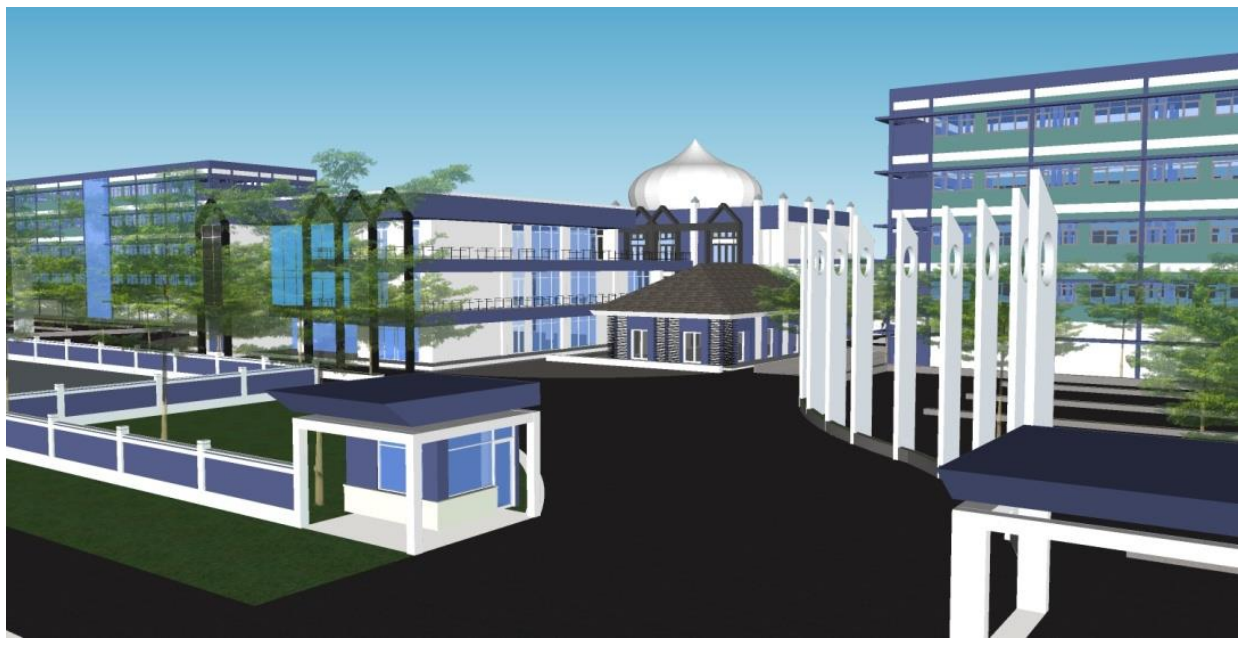

Gambar 36. Perspektif 5

\section{KESIMPULAN}

Sudah Sejak lama sudah berkembang pendidikan di Indonesia, namun pendidikan berbasis pesantren masih minim di daerah depok, sehingga cocok untuk perancangan pondok pesantren di depok.

Dari hasil perencanaan Pondok Pesantren Modern di depok ini dapat disimpulkan bahwa konsep berawal dari majunya bangunan di Indonesia yang menuju serba modern yang dipadukan dengan nuansa Islami. Penggunaan konsep ini dirasa tepat karena didaerah depok sendiri bangunan dengan konsep tersebut dirasa minim sehingga para santri dapat memahami apaitu konsep Modern. Transformasi bentuk bangunan mengadopsi dari Hadis Riwayat Bukhari dengan pendekatan Analogi dengan fungsi dan tema dari pondok pesantren Sedang dari segi pendekatan arsitektur, perancangan difokuskan pada segiteknologi bangunan. Strategi praktis komponen tumpukan al-quran yang tidak beraturan. Penggunaan komponen tumpukan al-quran yang tidak beraturan, merupakan produk modern, kemudian dipasang dan dirakit pada bangunan. Hal tersebut dimungkinkan karena kemajuan 
teknologi dan tuntutan kepraktisan dalam pembuatan bangunan.

\section{DAFTAR PUSTAKA}

Ching, Francis D.K and Cassandra Adams. (2001). Building Construction Ilustrated. Jakarta: Penerbit Erlangga

Ching, Francis D.K. Architecture, Form, Space and Order, New York Conference, Convention and Exhibition Facilities.
De Chaira, Joshep and Koppleman Lee E. (1975). Standar Perencanaan Tapak. Jakarta: Erlangga. Dinas Tata Kota Jakarta

Hartono, Poerbo,. (2000). Struktur dan Bangunan Tingkat Tinggi Jilid 2. Jakarta: Djambatan.

Kamus Besar Bahasa Indonesia, 1988. Jakarta : Dep. P\&K,

Sunarto, T., (1996). Data Arsitek Jilid 1. Jakarta: Erlangga.

Tangoro, D. (2006). Utilitas Bangunan. Jakarta: Universitas Indonesia 